doi: $10.2306 /$ scienceasia1513-1874.2012.38.283

\title{
Transesterification of waste frying oil for synthesizing biodiesel by KOH supported on coconut shell activated carbon in packed bed reactor
}

\author{
Achanai Buasri $^{\mathrm{a}, \mathrm{b}, *}$, Nattawut Chaiyut ${ }^{\mathrm{a}, \mathrm{b}}$, Vorrada Loryuenyong ${ }^{\mathrm{a}, \mathrm{b}}$, Chao Rodklum $^{\mathrm{a}}$, \\ Techit Chaikwan $^{\mathrm{a}}$, Nanthakrit Kumphan ${ }^{\mathrm{a}}$, Kritsanapong Jadee ${ }^{\mathrm{a}}$, Pathravut Klinklom ${ }^{\mathrm{a}}$, \\ Wittaya Wittayarounayut ${ }^{\mathrm{a}}$ \\ a Department of Materials Science and Engineering, Faculty of Engineering and Industrial Technology, \\ Silpakorn University, Nakhon Pathom 73000 Thailand \\ b National Centre of Excellence for Petroleum, Petrochemicals and Advanced Materials, \\ Chulalongkorn University, Bangkok 10330 Thailand
}

*Corresponding author, e-mail: achanai130@gmail.com

Received 9 Apr 2012

Accepted 1 Aug 2012

\begin{abstract}
Heterogeneous catalysis of transesterification using potassium hydroxide supported on coconut shell activated carbon (KOH/AC) catalyst was used to produce biodiesel from waste frying oil (WFO) and methanol. The effects of reaction temperature, methanol to oil molar ratio, catalyst bed height, reaction time, and reusability of catalyst on the conversion to fatty acid methyl ester in a packed bed reactor were studied. The results showed that increasing reaction temperature, methanol/oil molar ratio, catalyst bed height, and reaction time can enhance the conversion of WFO. The optimum conditions were a reaction temperature of $60^{\circ} \mathrm{C}$, methanol/oil molar ratio 25:1, catalyst bed height $250 \mathrm{~mm}$, and reaction time $2 \mathrm{~h}$ which yielded $86.3 \%$ of the conversion. $\mathrm{KOH} / \mathrm{AC}$ could be used repeatedly for 4 times without activity loss and no activation treatment was required. The fuel properties of biodiesel were determined.
\end{abstract}

KEYWORDS: heterogeneous catalyst

\section{INTRODUCTION}

In recent times, renewable energy is considered to be a pivotal solution to combat global warming and to stabilize the climate, through the reduction of greenhouse gas emissions. Biodiesel or fatty acid methyl ester (FAME) is receiving increasing attention as an environmentally friendly and renewable alternative for the petroleum based diesel fuel ${ }^{1}$. It is biodegradable and non-toxic. It has a more favourable combustion emission profile, such as low emissions of particulate matter and unburned hydrocarbons. $\mathrm{CO}_{2}$ produced by combustion of biodiesel can be recycled by photosynthesis, thereby minimizing the impact of biodiesel combustion on the greenhouse effect ${ }^{2,3}$. Biodiesel has a relatively high flash point which makes it less volatile and safer to transport or handle than petroleum diesel $^{4}$. It provides lubricating properties that can reduce engine wear and extend engine life. Therefore, biodiesel fuel is considered the best choice in bioenergy and has led to its use in many countries, especially in environmentally sensitive areas ${ }^{5}$.

In general, biodiesel is derived from a transester- ification reaction of triglycerides in vegetable oils or animal fats with alcohol (methanol or ethanol) under the presence of catalysts ${ }^{6}$. Transesterification of vegetable oil to biodiesel can be catalysed by bases, acids, and enzymes ${ }^{7}$. The commonly used homogeneous base catalysts are $\mathrm{KOH}, \mathrm{NaOH}$, and their alkoxides. Homogeneous acids catalysts, such as $\mathrm{HCl}$ and $\mathrm{H}_{2} \mathrm{SO}_{4}$ require a long reaction time. Therefore, homogeneous alkali-catalysed transesterification is much faster than acid-catalysed one ${ }^{8,9}$. However, a large amount of water is required to remove the residual catalyst from bulk biodiesel after reaction ${ }^{10}$. For this reason, heterogeneous catalysis is likely to be used replacing the conventional method in the near future ${ }^{11}$. It has a simpler separation process compared to homogeneous catalyst process ${ }^{12}$.

Activated carbon (AC) has proved to be highly effective as a catalyst support in liquid and vapour phase reactions. The properties of AC make it advantageous for use as a catalyst support in transesterification reaction. It has a large surface area which allows the catalyst to disperse over it largely and effectively ${ }^{13}$. It can be produced from a variety of 
raw materials. However, coconut and palm shells are mainly used as a raw material because it can be sought in the country ${ }^{14}$. These renewable agricultural wastes are cost-effective alternatives to more expensive and polluting precursors like coal for the production of $\mathrm{AC}^{15}$.

The increasing production of waste cooking oil or waste frying oil (WFO) from household and industrial sources is a growing problem all around the world. This residue is regularly poured down the drain, resulting in problems for waste water treatment plants and energy loss, or is integrated into the food chain through animal feeding, thus becoming a potential cause of human health problems ${ }^{16,17}$. The objective of this work was to optimize the process for biodiesel production from WFO using potassium hydroxide supported on coconut shell activated carbon $(\mathrm{KOH} / \mathrm{AC})$. The effects of reaction temperature, methanol to oil molar ratio, catalyst bed height, reaction time, and reusability of catalyst are systematically investigated.

\section{MATERIALS AND METHODS}

\section{Materials}

WFO was purchased from a local market without further treatment. The free fatty acid (FFA) and water content of the oil were measured to be 39.14 and $0.11 \mathrm{wt} \%$, respectively. Non-oil components of the WFO were removed by separation. Filter paper was used to remove impurities from the oil feedstock before use. The AC used in this work was coconut shell-based, produced by chemical activation process. All other chemicals were analytical grade reagents (Merck, $>99 \%$ purity) and were used as received.

\section{Catalyst preparation}

The coconut shell was cleaned with water to remove fines and dirt, and dried at $100{ }^{\circ} \mathrm{C}$ for $12 \mathrm{~h}$. The dried sample was crushed with a grinder and sieved to a particle size 1.8-2.8 $\mathrm{mm}$. It was soaked in phosphoric acid $\left(\mathrm{H}_{3} \mathrm{PO}_{4}\right)$ solution with an impregnation ratio of 1.7 for $24 \mathrm{~h}$ at ambient temperature ${ }^{18}$. After that, it was dried in oven at $100{ }^{\circ} \mathrm{C}$ for $12 \mathrm{~h}$. The resulted sample was further activated in a horizontal automatic tubular furnace at $500{ }^{\circ} \mathrm{C}$ for $24 \mathrm{~h}$ under nitrogen atmosphere $^{19}$. After cooling, the $\mathrm{AC}$ was washed successively several times with distilled water until the $\mathrm{pH}$ became neutral. The washed sample was dried at $110^{\circ} \mathrm{C}$ for $12 \mathrm{~h}$ to obtain $\mathrm{AC}$ of coconut shell as the final product, cooled in a desiccator, and stored in glass containers.

A potassium containing solution was prepared by

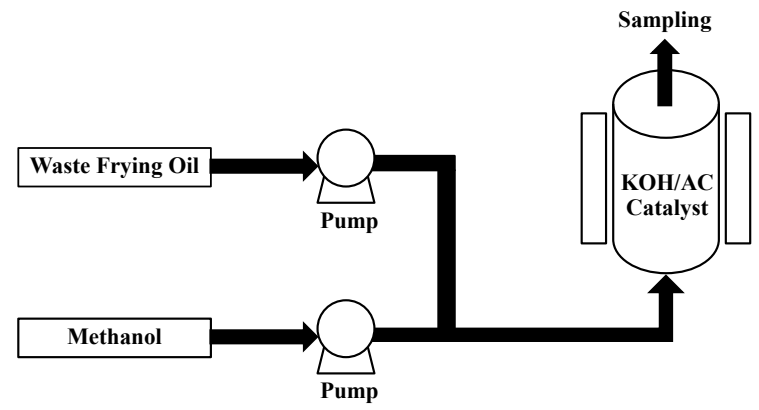

Fig. 1 Scheme of the packed bed reactor for the continuous transesterification.

dissolving $\mathrm{KOH}$ in distilled water. $\mathrm{AC}$ was divided in $50 \mathrm{~g}$ portions and placed in beakers. $\mathrm{KOH}$ solution $(750 \mathrm{ml})$ with initial concentration of $0.40 \mathrm{~g} / \mathrm{ml}$ was added. AC together with the $\mathrm{KOH}$ solution was then agitated at ambient temperature for $24 \mathrm{~h}$. The amount of adsorbed $\mathrm{KOH}$ was measured by gravimetrical $\operatorname{method}^{13}$.

\section{Catalyst characterization}

The morphology of $\mathrm{AC}$ and $\mathrm{KOH} / \mathrm{AC}$ catalyst was conducted using a scanning electron microscope (SEM). The SEM images of the representative sample were obtained from a Camscan-MX 2000. Characterization by $\mathrm{N}_{2}$ adsorption-desorption isotherms at $77 \mathrm{~K}$ were obtained using a Quantachrome instrument (Autosorb-1 Model No. ASIMP.VP4). The surface area was calculated using the Brunauer-Emmett-Teller (BET) equation and the mean pore diameter and pore volume was obtained by applying the Barret-JoynerHalenda method on the desorption branch ${ }^{20}$.

\section{Instrumentation}

The continuous transesterification was performed in a packed bed reactor. The scheme of the packed bed reactor is shown in Fig. 1. The reactor consists of a water-jacketed stainless steel column with an external diameter of $60 \mathrm{~mm}$ and a height of $345 \mathrm{~mm}$. The column was packed with $\mathrm{KOH} / \mathrm{AC}$ solid-base catalyst. WFO and methanol were fed into the system using two separate raw material pumps. The reaction temperature was controlled by a heater to keep constant temperature with an error of $\pm 1.0^{\circ} \mathrm{C}$. The temperature difference between the inlet and the outlet was below $1.0^{\circ} \mathrm{C}$ during all the runs. Temperature and pressure of the system were monitored by temperature indicator and pressure gauges. The sample obtained was purified by reduced pressure distillation to remove excess methanol and water generated during reaction. 


\section{Continuous transesterification reaction}

The synthesis of FAME from WFO and methanol was carried out in a packed bed reactor with flow rate of reactant $1 \mathrm{ml} / \mathrm{min}$. The effects of reaction temperature $\left(50-80{ }^{\circ} \mathrm{C}\right)$, methanol to oil molar ratio $(10: 1-30: 1)$, catalyst bed height (100-300 mm), reaction time (1$3 \mathrm{~h}$ ), and reusability of catalyst (1-4 times) on the conversion to methyl ester were studied. Composition of the methyl ester was analysed with a gas chromatograph equipped with a flame ionization detector and a capillary column $30 \mathrm{~m} \times 0.32 \mathrm{~mm} \times 0.25 \mu \mathrm{m}(\mathrm{DB}-$ WAX, Carbowax 20M).

\section{RESULTS AND DISCUSSION}

\section{Characterization of catalyst}

In general, the high porosity of AC provides a large surface area for attachment of alkoxides. The amount of adsorbed $\mathrm{KOH}$ was measured by gravimetrical method. The total loading content of the potassium salts was $30.1 \%$ by weight based on the weight of AC. Fig. 2 shows the SEM images of $\mathrm{AC}$ and $\mathrm{KOH} / \mathrm{AC}$ which illustrate the porous nature of the materials. The figure shows that the metal loading affected the partial metal coverage on AC surface. When metal loading was increased, $\mathrm{AC}$ was covered with metal almost all the surface, increasing the active sites ${ }^{14}$. The photograph showed a good dispersion of $\mathrm{KOH}$ on the surface of AC. Based on these results, after loading of $\mathrm{KOH}, \mathrm{AC}$ retained its structure that was important for catalysis and therefore the potassium species were found highly distributed upon the surface of the support ${ }^{1}$.

The physical properties of $\mathrm{AC}$ and $\mathrm{KOH} / \mathrm{AC}$ are summarized in Table 1. The AC had a large BET surface area $\left(898.6 \mathrm{~m}^{2} / \mathrm{g}\right)$ and pore volume $\left(0.905 \mathrm{~cm}^{3} / \mathrm{g}\right)$, and presented a uniform pore size. $\mathrm{KOH} / \mathrm{AC}$ presented lower values for surface area $\left(284.2 \mathrm{~m}^{2} / \mathrm{g}\right)$ and pore volume $\left(0.211 \mathrm{~cm}^{3} / \mathrm{g}\right)$ relative to AC. The significant reduction in BET surface area from virgin $\mathrm{AC}$ to the $\mathrm{KOH} / \mathrm{AC}$ catalyst with $30.1 \mathrm{wt} \%$ indicates filling of $\mathrm{KOH}$ molecules into the $\mathrm{AC}$ pores ${ }^{13}$. It can be seen that the catalyst resulted in a strong increase in the active sites. This assumption is supported by the SEM images of $\mathrm{AC}$ and $\mathrm{KOH} / \mathrm{AC}$.

\section{Effect of transesterification parameter}

The effects of reaction temperature on the conversion of WFO to FAME was studied by varying the temperature from $50-80{ }^{\circ} \mathrm{C}$, and keeping fixed $25: 1$ methanol to oil molar ratio, $250 \mathrm{~mm}$ catalyst bed height, and $1 \mathrm{ml} / \mathrm{min}$ flow rate of reactant with atmospheric pressure. Fig. 3 shows that an increase
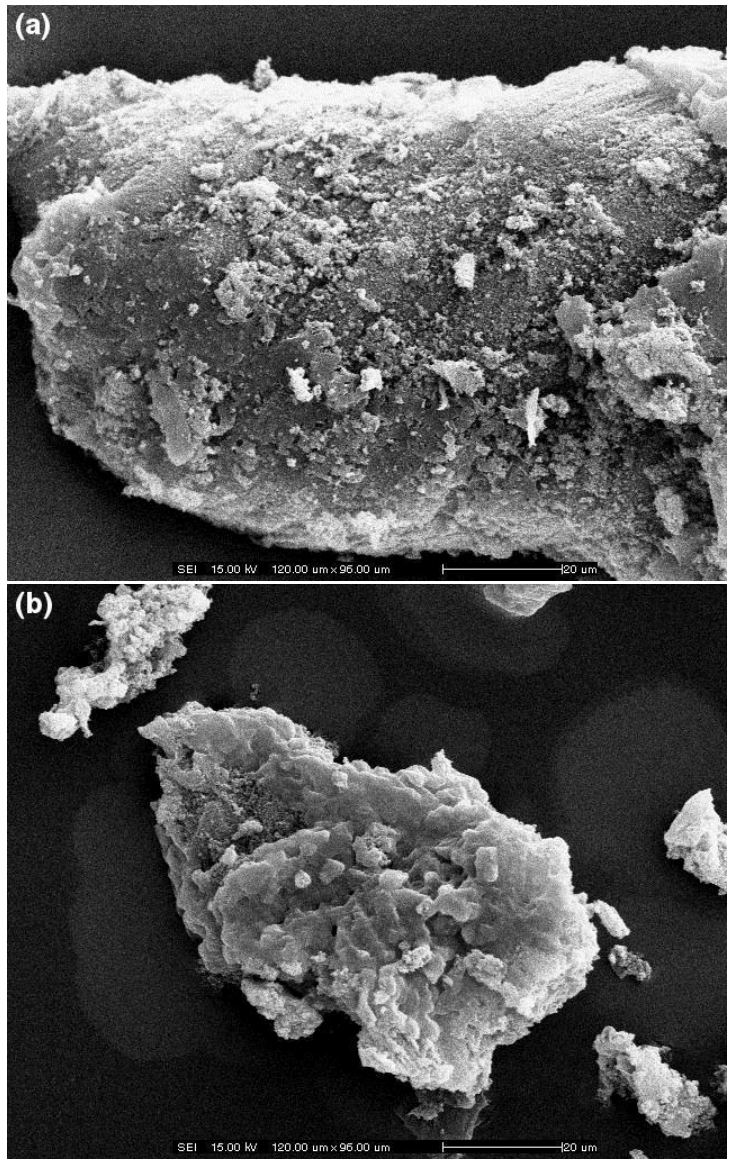

Fig. 2 SEM micrograph of samples: (a) AC and (b) $\mathrm{KOH} / \mathrm{AC}$.

Table 1 Physical properties of AC and KOH/AC.

\begin{tabular}{lcc}
\hline Physical property & \multicolumn{2}{c}{ Material } \\
\cline { 2 - 3 } & $\mathrm{AC}$ & $\mathrm{KOH} / \mathrm{AC}$ \\
\hline BET surface $\operatorname{area}\left(\mathrm{m}^{2} / \mathrm{g}\right)$ & 898.6 & 284.2 \\
Pore volume $\left(\mathrm{m}^{3} / \mathrm{g}\right)$ & 0.905 & 0.211 \\
Mean pore diameter $(\AA)$ & 45.22 & 92.43 \\
\hline
\end{tabular}

in temperature led to higher reaction conversions. At the beginning of reaction, conversion increased because reactant contacted fresh catalyst. Then the conversions decreased due to slightly deactivated but stabilized catalyst, and the conversions reached steady state at all temperatures. At $50^{\circ} \mathrm{C}$, the least conversion $(61.6 \%)$ was observed. At $60^{\circ} \mathrm{C}$, the reaction conversion was highest (86.3\%). Increasing the temperature to 70 and $80^{\circ} \mathrm{C}$, a fluctuation was observed with lower conversion. The temperatures of 70 and $80^{\circ} \mathrm{C}$ were higher than the boiling point of methanol $\left(65^{\circ} \mathrm{C}\right)$. Therefore the vapour-liquid phases of the reaction 


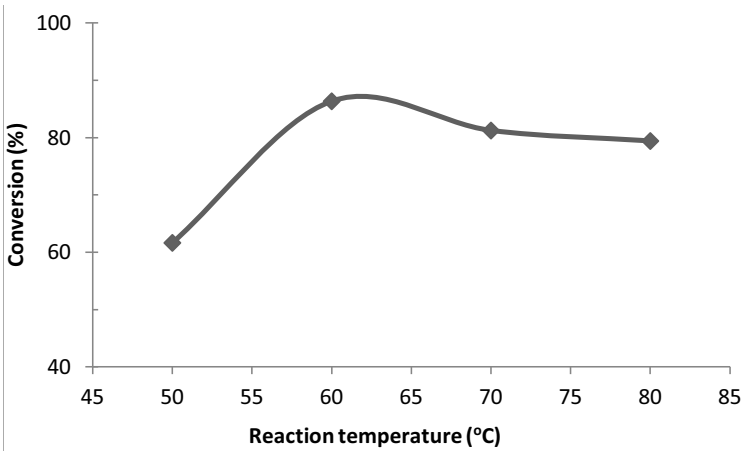

Fig. 3 Effect of reaction temperature on the conversion of transesterification in packed bed reactor.

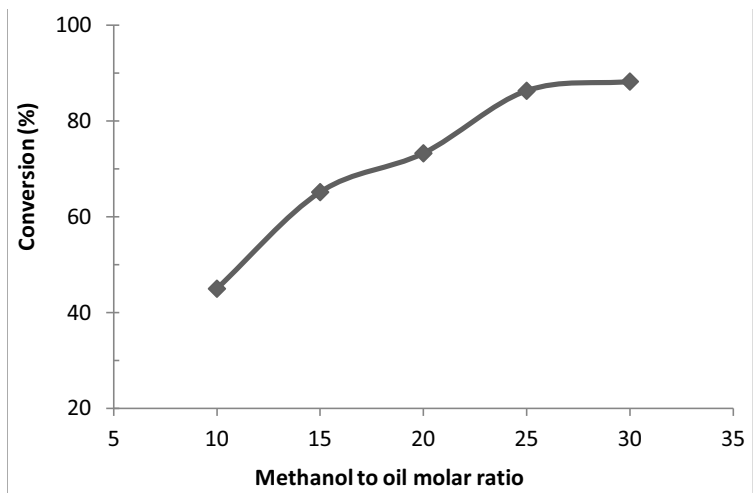

Fig. 4 Effect of methanol to oil molar ratio on the conversion of transesterification in packed bed reactor.

mixture may be responsible for this fluctuation ${ }^{21}$. Thus the highest reaction temperature was limited to $60{ }^{\circ} \mathrm{C}$ for the transesterification of WFO in packed bed reactor.

The excess of methanol is necessary because it can increase the rate of methanolysis. Normally, stoichiometric molar ratio of methanol to oil is near 6:1 when the homogeneous alkali-catalysed process is used. However, it increases to 20:1, even 50:1, in the heterogeneous alkali-catalysed process to ensure high conversion ${ }^{22}$. The conversion of WFO achieved $86.3 \%$ at $60{ }^{\circ} \mathrm{C}$ and $250 \mathrm{~mm}$ catalyst bed height when the ratio of methanol to oil was 25:1 (Fig. 4). The more excess of methanol was fed, the higher conversion of WFO to FAME was achieved in the same reaction time. However, when the ratio was over $25: 1$, the increment of conversion was small.

The catalyst bed height in the packed bed reactor is associated with the residence time during continuous transesterification. The WFO conversion increased rapidly from $51.1 \%$ to $89.7 \%$ with the increase of the catalyst bed height from 100 to $300 \mathrm{~mm}$.

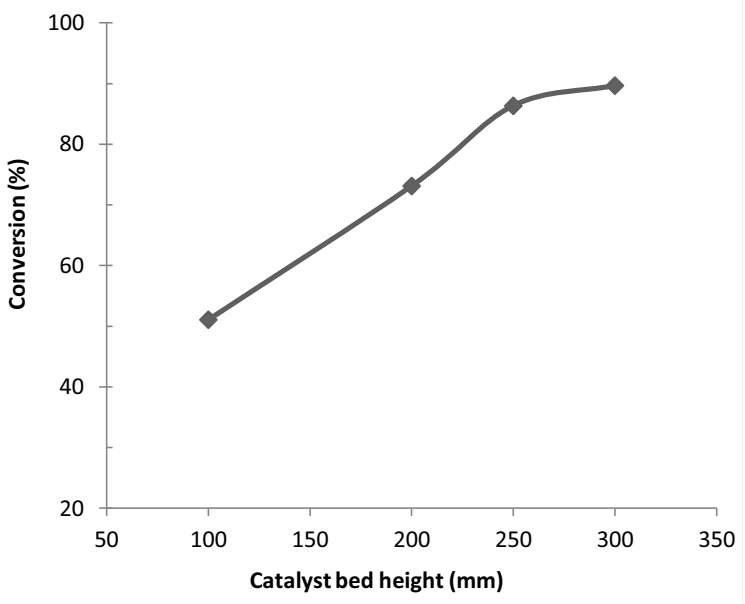

Fig. 5 Effect of catalyst bed height on the conversion of transesterification in packed bed reactor.

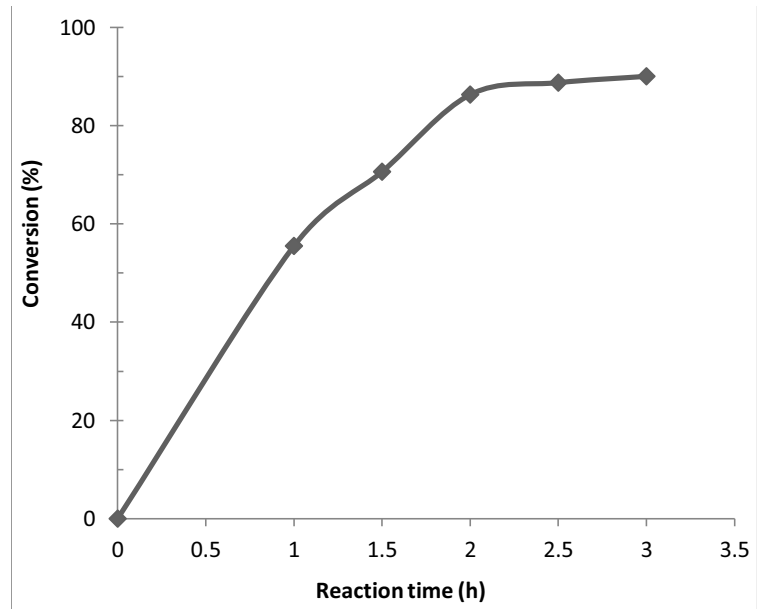

Fig. 6 Effect of reaction time on the conversion of transesterification in packed bed reactor.

In particular, WFO conversion was over $85 \%$ when catalyst bed height was over $250 \mathrm{~mm}$ (Fig. 5). It demonstrates that a high catalyst bed height provides a longer reaction time and more active sites to promote the reaction between WFO and methanol at a given flow rate ${ }^{23}$.

The corresponding conversion of waste oil with the reaction time is shown in Fig. 6. The conversion of WFO increased from $55.5 \%$ to $86.3 \%$ with an increase of reaction time from 1 to $2 \mathrm{~h}$. However, from reaction time $2-3 \mathrm{~h}$, the conversion only increased a little. This can be explained by the fact that the transesterification reaction between WFO and methanol is reversible. When the reaction time is long enough, the hydrolysis reaction of FAME will start to generate more FFA 


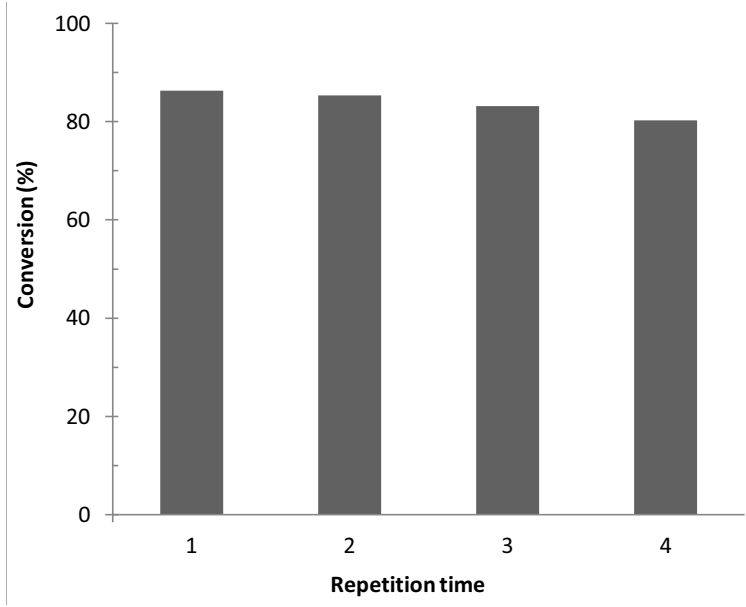

Fig. 7 Effect of repetition time on the conversion of transesterification in packed bed reactor.

and alcohol. Thus from an economical point of view, it reveals that it is not necessary to spend a long time to increase the conversion of waste oil when the yield of FAME has been increased enough to avoid saponification and hydrolysis reaction in the transesterification reaction ${ }^{24}$.

Reusability is one of the most important properties of a solid catalyst. In this experiment, the reactants and catalyst were introduced into the packed bed reactor for transesterification. $\mathrm{KOH} / \mathrm{AC}$ catalyst was collected after the reaction and fresh reactants added without any treatment. WFO conversion, determined after each catalyst collection, was employed to evaluate the reusability. The operating conditions, i.e., a reaction temperature of $60^{\circ} \mathrm{C}$, methanol to oil molar ratio $25: 1$, and catalyst bed height $250 \mathrm{~mm}$ were determined by the operational parameters employed in the reactor. Under those conditions, a high WFO conversion was obtained (Fig. 7). WFO conversions exhibited no apparent decrease and surmounted $80 \%$ in every run for 4 times. As shown in Table 2, this value is within the range reported by other researchers ${ }^{1,25,26}$. This heterogeneous catalyst showed high stability and reusability for transesterification without loss of its catalytic activity during reaction. Small loss of the catalyst is an important factor for good catalyst reusability ${ }^{27}$.

\section{Characterization of biodiesel}

The fuel properties of biodiesel obtained in this work are summarized in Table 3. It can be seen that most of its properties are in the range of fuel properties as described in the latest Thai and American standards for biodiesel ${ }^{28-30}$.
Table 2 Reusability comparison between supported catalysts.

\begin{tabular}{lccl}
\hline Catalyst & Repetition time & Conversion (\%) & Reference \\
\hline $\mathrm{KOH} / \mathrm{AC}$ & 4 & 80.3 & This work \\
$\mathrm{KOH} / \mathrm{AC}$ & 3 & 89.3 & Ref. 1 \\
$\mathrm{CaO} / \mathrm{AC}$ & 4 & 70.1 & Ref. 24 \\
$\mathrm{K}_{2} \mathrm{CO}_{3} / \mathrm{AC}$ & 3 & 97.4 & Ref. 25 \\
\hline
\end{tabular}

Table 3 The fuel properties of biodiesel.

\begin{tabular}{lccc}
\hline Fuel properties & $\begin{array}{c}\text { Biodiesel } \\
\text { in this work }\end{array}$ & $\begin{array}{c}\text { Thai } \\
\text { standard }\end{array}$ & $\begin{array}{c}\text { ASTM } \\
\text { D6751-02 }\end{array}$ \\
\hline $\begin{array}{l}\text { Kinematic viscosity } \\
\text { at } 40^{\circ} \mathrm{C}\left(\mathrm{mm}^{2} / \mathrm{s}\right)\end{array}$ & 4.7 & $3.5-5.0$ & $1.9-6.0$ \\
$\begin{array}{l}\text { Density at } 15^{\circ} \mathrm{C} \\
\left(\mathrm{kg} / \mathrm{m}^{3}\right)\end{array}$ & 891 & $860-900$ & $870-900$ \\
$\begin{array}{l}\text { Flash point }\left({ }^{\circ} \mathrm{C}\right) \\
\text { Cloud point }\left({ }^{\circ} \mathrm{C}\right)\end{array}$ & 177 & 120 & 130 \\
Water content $(\mathrm{wt} \%)$ & 0.04 & 0.05 max & 0.03 max \\
\hline
\end{tabular}

\section{CONCLUSIONS}

This investigation showed that transesterification of WFO can be achieved by heterogeneous catalysis with $\mathrm{KOH} / \mathrm{AC}$. The optimum condition, which yielded a conversion of WFO of nearly $86 \%$, was a reaction temperature of $60^{\circ} \mathrm{C}$, methanol/oil molar ratio $25: 1$, and reaction time $2 \mathrm{~h}$ with a catalyst bed height $250 \mathrm{~mm}$ in packed bed reactor. The experimental results show that $\mathrm{KOH} / \mathrm{AC}$ had excellent activity and stability during transesterification. The catalyst was used for 4 times and no apparent activity loss was observed. The fuel properties of the biodiesel so obtained meet all biodiesel standards. As a solid catalyst, $\mathrm{KOH} / \mathrm{AC}$ can decrease the cost of biodiesel and the steps of purification. It has potential for industrial application in the transesterification of WFO to FAME.

Acknowledgements: This work is supported by Silpakorn University Research and Development Institute (SURDI 52/02/06.01-53/02/04.01). The authors acknowledge sincerely the Department of Materials Science and Engineering (MSE), Faculty of Engineering and Industrial Technology, Silpakorn University and National Centre of Excellence for Petroleum, Petrochemicals, and Advanced Materials (PPAM), Chulalongkorn University for supporting and encouraging this investigation.

\section{REFERENCES}

1. Baroutian S, Aroua MK, Raman AAA, Sulaiman NMN (2011) A packed bed membrane reactor for production 
of biodiesel using activated carbon supported catalyst. Bioresour Tech 102, 1095-102.

2. Körbitz W (1999) Biodiesel production in Europe and North America, an encouraging prospect. Renew Energ 16, 1078-83.

3. Agarwal AK, Das LM (2001) Biodiesel development and characterization for use as a fuel in compression ignition engines. J Eng Gas Turb Power 123, 440-7.

4. Krawczyk T (1996) Biodiesel-alternative fuel makes inroads but hurdles remain. Inform 7, 801-29.

5. Buasri A, Chaiyut N, Ketlekha P, Mongkolwatee W, Boonrawd S (2009) Biodiesel production from crude palm oil with a high content of free fatty acids and fuel properties. CMU J Nat Sci 8, 115-24.

6. Simasatitkul L, Siricharnsakunchai P, Patcharavorachot Y, Assabumrungrat S, Arpornwichanop A (2011) Reactive distillation for biodiesel production from soybean oil. Kor J Chem Eng 28, 649-55.

7. Du W, Xu Y, Liu D, Zhang J (2004) Comparativestudy on lipase-catalyzed transformation of soybean oil for biodiesel production with different acyl acceptors. J Mol Catal B 30, 125-9.

8. Vicente G, Martínez M, Aracil J (2004) Integrated biodiesel production: a comparison of different homogeneous catalysts systems. Bioresour Tech 92 297-305.

9. Furuta S, Matsuhashi H, Arata K (2006) Biodiesel fuel production with solid amorphous-zirconia catalysis in fixed bed reactor. Biomass Bioenerg 30, 870-3.

10. Shin J, Kim H, Hong SG, Kwon S, Na YE, Bae SH, Park WK, Kang KK (2012) Effects of ultrasonification and mechanical stirring methods for the production of biodiesel from rapeseed oil. Kor J Chem Eng 29, 460-3.

11. Samart C, Sreetongkittikul P, Sookman C (2009) Heterogeneous catalysis of transesterification of soybean oil using KI/mesoporous silica. Fuel Process Tech 90, 922-5.

12. Hameed BH, Goh CS, Chin LH (2009) Process optimization for methyl ester production from waste cooking oil using activated carbon supported potassium fluoride. Fuel Process Tech 90, 1532-7.

13. Baroutian S, Aroua MK, Raman AAA, Sulaiman NMN (2010) Potassium hydroxide catalyst supported on palm shell activated carbon for transesterification of palm oil. Fuel Process Tech 91, 1378-85.

14. Buasri A, Chaiyut N, Nakweang C (2011) Preparing activated carbon from palm shell for biodiesel fuel production. Chiang Mai J Sci 38, 572-8.

15. Ribeiro AM, Loureiro JM (2002) Simulation of toxic gases and vapours removal by activated carbon filters. Chem Eng Sci 57, 1621-6.

16. Costa Neto PR, Rossi LFS, Zagonel GF, Ramos LP (2000) Produção de biodiesel alternativo ao óleo diesel através da transesterificação de óleo de soja usado em frituras. Quim Nova 23, 531-7.

17. Zaher F (2003) Utilization of used frying oil as diesel engine fuel. Energ Sourc 25, 819-26.

18. Gratuito MKB, Panyathanmaporn T, Chumnanklang RA, Sirinuntawittaya N, Dutta A (2008) Production of activated carbon from coconut shell: Optimization using response surface methodology. Bioresour Tech 99, 4887-95.

19. Tongpoothorn W, Sriuttha M, Homchan P, Chanthai S, Ruangviriyachai C (2011) Preparation of activated carbon derived from Jatropha curcas fruit shell by simple thermo-chemical activation and characterization of their physico-chemical properties. Chem Eng Res Des 89, 335-40.

20. Alba-Rubio AC, Vila F, Martín-Alonso DM, Ojeda M, Mariscal R, López-Granados ML (2010) Deactivation of organosulfonic acid functionalized silica catalysts during biodiesel synthesis. Appl Catal B Environ 95, 279-87.

21. Hsieh LS, Kumar U, Wu JCS (2010) Continuous production of biodiesel in a packed-bed reactor using shellcore structural $\mathrm{Ca}\left(\mathrm{C}_{3} \mathrm{H}_{7} \mathrm{O}_{3}\right)_{2} / \mathrm{CaCO}_{3}$ catalyst. Chem Eng $J$ 158, 250-6.

22. Zhang Y, Dubé MA, McLean DD, Kates M (2003) Biodiesel production from waste cooking oil: 1. Process design and technological assessment. Bioresour Tech 89, 1-16.

23. Feng Y, Zhang A, Li J, He B (2011) A continuous process for biodiesel production in a fixed bed reactor packed with cation-exchange resin as heterogeneous catalyst. Bioresour Tech 102, 3607-9.

24. Lu P, Yuan Z, Li L, Wang Z, Luo W (2010) Biodiesel from different oil using fixed-bed and plug-flow reactors. Renew Energ 35, 283-7.

25. Buasri A, Ksapabutr B, Panapoy M, Chaiyut N (2012) Biodiesel production from waste cooking palm oil using calcium oxide supported on activated carbon as catalyst in a fixed bed reactor. Korean J Chem Eng (in press).

26. Fan M, Zhang $P$ (2007) Activated carbon supported $\mathrm{K}_{2} \mathrm{CO}_{3}$ catalysts for transesterification of dimethyl carbonate with propyl alcohol. Energ Fuel 21, 633-5.

27. Jiang ST, Zhang FJ, Pan LJ (2010) Sodium phosphate as a solid catalyst for biodiesel preparation. Braz $J$ Chem Eng 27, 137-44.

28. Chongkhong S, Tongurai C, Chetpattananondh P, Bunyakan C (2007) Biodiesel production by esterification of palm fatty acid distillate. Biomass Bioenerg 31, 563-8.

29. Buasri A, Chaiyut N, Loryuenyong V, Pin-Ngern K, Tonprasert N, Dangnuan S (2012) Production of fatty acid methyl ester by esterification of waste frying oil with methanol using acidified silica as heterogeneous. $J$ Biobased Mater Bio (in press).

30. Buasri A, Ksapabutr B, Panapoy M, Chaiyut N (2012) Synthesis of biofuel from palm stearin using an activated carbon supported catalyst in packed column reactor. Adv Sci Lett (in press). 